\title{
THE PRODUCTION AND SPECIFICATION ANALYSIS OF AVIATION BIOFUEL AS THE ALTERNATIVE FUEL OF AIRPLANE
}

\author{
Cheppy Asnadi, Septhian Marno, Poppy Sri Lestari, Difany Tsabita Islami, Nelliza Putri, Wawan Rustyawan
}

\begin{abstract}
CO}_{2}$ emissions and scarcity of petroleum supplies can be reduced by the use of renewable energy sources. This has led to the development of low emission aviation turbine fuel derived from vegetable materials. The process used Hydroprocessed Esters and Fatty Acids (HEFA) that consisted of hydrotreating and isomerization. This experiment consisted of production and analysis. The production of aviation biofuel developed based on coconut oil through the process of hydrotreating deoxygenation (HDO) and hydrotreating isomerization (HDI) on the hydrotreater reactor. Further analysis of aviation biofuel products and aviation biofuel blending includes Total Acid Number (TAN), existent gum, density at $15{ }^{\circ} \mathrm{C}$, flash point, smoke point, freezing point, distillation, total sulfur content, distribution of $\mathrm{C}_{10}-\mathrm{C}_{14}$ carbon, and levels of Iso-Paraffin Olefin Naphthene (PION). Based on the experimental results, it can be concluded that the Aviation Biofuel complied for TAN, density at $15^{\circ} \mathrm{C}$, and freezing point parameters. Aviation Biofuel blending of $2 \%, 5 \%$, and $10 \%$ were in accordance with the Aviation Biofuel Defence Standard 91-91 for all parameters.
\end{abstract}

Keyword: coconut oil, aviation biofuel, hydrotreating deoxygenation, hydrotreating isomerization

\section{INTRODUCTION}

The fuel oil in the aviation industry is aviation gasoline (avgas) which is used as a fuel for piston engine airplanes and aviation turbine fuel used by turbine or jet engine airplanes [1]. Jet fuel is almost exclusively extracted from the kerosene fraction from crude oil, which filters between the gasoline fraction and the diesel fraction [2]. Aviation turbine fuel as a fuel can be divided into 2 types namely kerosenebased (Jet A and Jet A-1) and naphtha-based mixture (Jet B). Jet A-1 is the most widely used aviation turbine fuel worldwide, Jet A is only used in the United States, and Jet B is only used in very cold climates because of its more explosive nature [3].

The use of petroleum fuels to obtain hydrocarbons and energy sources continuously raises new problems, i.e. global warming which causes an increase in $\mathrm{CO}_{2}$ concentrations in the air [4]. Increased $\mathrm{CO}_{2}$ emissions in the air by aviation fuel, caused by the longer carbon chain, the greater the $\mathrm{CO}_{2}$ emissions produced. Aviation Turbine Fuel has a hydrocarbon range greater than avgas that is $\mathrm{C}_{10}-\mathrm{C}_{14}$, whereas avgas $\mathrm{C}_{5}-\mathrm{C}_{10}$.

International Air Transport Association (IATA) states air transportation is responsible for $2 \%$ or \pm 740 million tons of carbon gas emissions in the world each year. Therefore, IATA made a policy regarding the growth of carbon emissions from aircraft fuel by $0 \%$ starting in 2020 and reducing carbon emissions by up to $50 \%$ by $2050 . \mathrm{CO}_{2}$ emissions and scarcity of petroleum supplies can be reduced by the use of renewable energy sources. IATA developed a fourpillar green aviation strategy with one of the strategies being the use of aviation biofuels with a target of blending it by $30 \%$ in 2030 and $50 \%$ in 2050 [5].
This has led to the development of low emission aviation turbine fuel derived from vegetable materials. Coconut oil which is used as the basis for aviation biofuel is usually made from copra with the manufacturing process using high heat. Sometimes experts include biofuel in the second generation biofuel group or also referred to as one and a half generation because the material is still in the form of vegetable oil while the process technology is quite advanced [6].

Minister of Energy and Mineral Resources (ESDM) Regulation No. 12 of 2015 set the use of vegetable materials (biofuel) as a mixture of petroleum fuels for air transportation of at least $2 \%$ in 2016 and 5\% in 2025 [7] and the company policy of PT Pertamina (Persero) a maximum of $10 \%$ aviation biofuel blending, then the experiment was conducted for blending variations were $2 \%, 5 \%$, and $10 \%$.

The purpose of this experiment was to make aviation biofuel as an alternative fuel for airplanes and to mix with aviation fuel (blending) according to established standards. Testing specifications using two standard references, namely aviation biofuel specifications refer to the Indonesian National Standard SNI: 8674 in 2018 about pure aviation biofuel and blending aviation biofuel refers to Defence Standard 91-91 Turbine Fuel, Kerosene Type, AVTUR 2011 [8].

\section{MATERIAL AND METHOD}

\section{Equipment}

The equipment used consist of main and supporting equipment. The main equipment used were the biofuel reactor pilot plant hydrotreater unit, Gas Chromatography (GC) Agilent Technologies 
7890A, GC PAC 7890B, VIDA density meter, automatic smoke point tester, Scavini freezing point tester, Abel Tanaka flash point, automatic OptiDist PAC distillation, micro burette $10 \mathrm{~mL}$, existent gum evaporator bath Petro test, PAN Analytical X-Ray Fluorescence (XRF). Supporting equipment used were furnace, beaker gum, flow steamer, analytical balance, vacuum Erlenmeyer, dropper pipette, 1000 $\mathrm{mL}$ measuring flask, $250 \mathrm{~mL}$ measuring flask, cup beaker, measuring cup, vial bottle, $50 \mathrm{~mL}$ and 100 $\mathrm{mL}$ volumetric pipette, and $20 \mathrm{~mL}$ Mohr pipette.

\section{Material}

The material used consists of test materials and chemicals. Test materials used were coconut oil, bio aviation turbine fuel of HDI products, bio aviation turbine fuel of HDO products, and aviation fuel. The chemicals used were toluene, iso-propyl alcohol (IPA), acetone, nitrogen gas, $0.1 \mathrm{~N}$ alcoholic $\mathrm{KOH}$, phenolphthalein (PP) indicator, distilled water, pnaphtholbenzein indicator, and metal-based catalyst.

\section{Method}

In this aviation biofuel manufacturing research used a biofuel pilot plant hydrotreater unit. Processes that take place in a pilot plant biofuels unit were hydrotreating and hydrocracking. The hydrotreating process of oil triglycerides from plants through a hydrotreating catalyst in the presence of hydrogen gas involves a complex reaction consisting of HDO, DCO (decarboxylation and decarbonation), addition reactions, cracking, isomerization, and cyclization. The n-paraffin or alkane hydrocarbon compound obtained through triglyceride conversion involves the hydrogenation of a double bond in the fatty acid alkyl chain, saturated triglyceride hydrogenolysis to fatty acids and subsequently undergoes $\mathrm{HDO}$, deCO, and $\mathrm{deCO}_{2}$ reactions in fatty acids. The alkane products formed can continue to experience cracking, isomerization, or cyclization reactions [9].

In this unit, coconut oil was processed through a catalytic process using hydrogen gas (hydro processing). The process of aviation biofuel production was done by the process of Hydroprocessed Esters and Fatty Acids (HEFA). The HEFA process consisted of two reaction stages, namely hydrotreating and isomerization. The hydrotreating step used in this process was the deoxygenation or removal of oxygen groups in fatty acids by hydrogen gas to form long-chain (n-paraffin) hydrocarbons. The isomerization step was carried out to make nparaffin into its isomeric form. This technique was chosen because it could be used on an industrial scale, operating costs were cheaper and the feed used was vegetable oil.

This experiment consists of two stages, namely production and analysis. The Production of aviation biofuel developed at PT Pertamina Research and Technology Center (RTC) based on coconut oil through the process of hydrotreating deoxygenation (HDO) (Fig. 1a) and hydrotreating isomerization (HDI) (Fig. 1b) on the hydrotreater reactor. This technique was chosen because the bait used was vegetable oil and could be used on an industrial scale. Further analysis of aviation biofuel products and aviation biofuel blending includes Total Acid Number (TAN) [10], existent gum [11], density at a temperature of $15{ }^{\circ} \mathrm{C}$ [12], flash point [12], smoke point [13], freezing point [11], distillation [14], total sulfur content, distribution of $\mathrm{C}_{10}-\mathrm{C}_{14}$ carbon, and levels of Iso-Paraffin Olefin Naphthene (PION) [11].

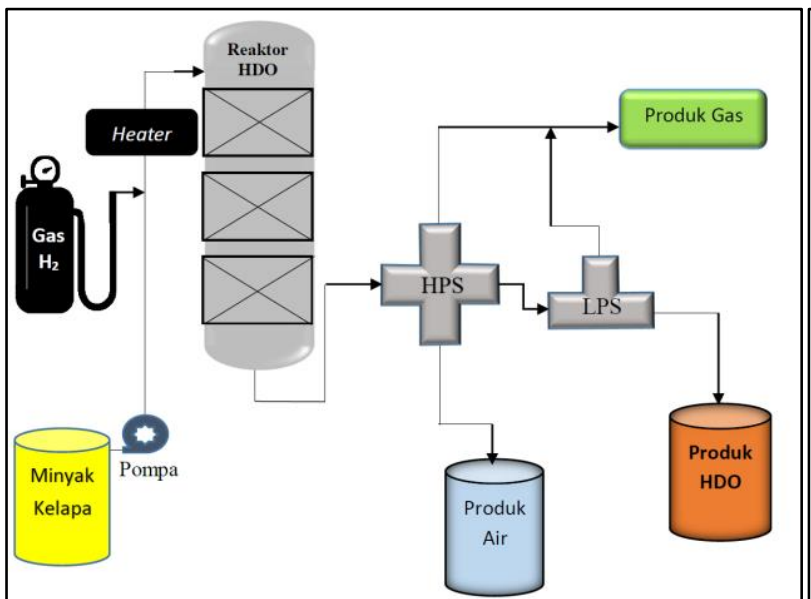

(a)

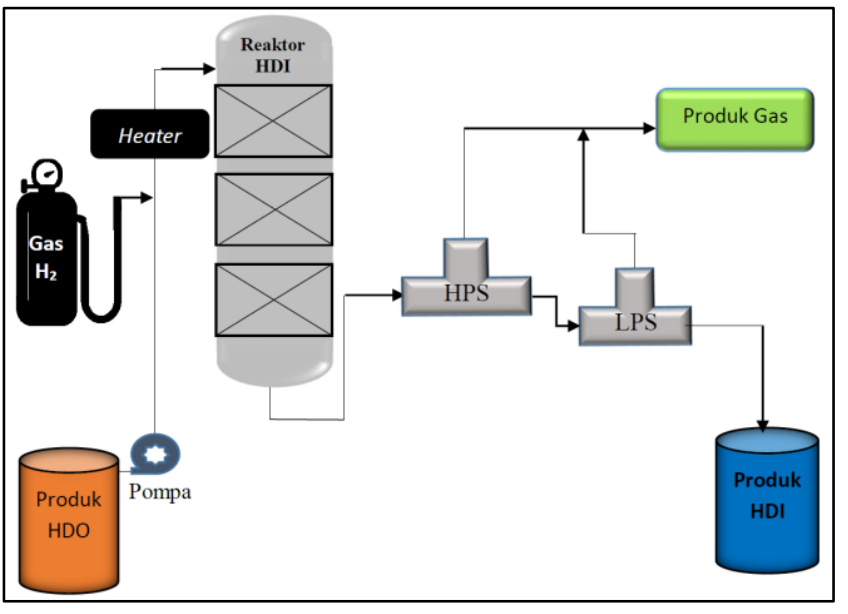

(b)

Fig. 1. HDO Reactor (a) HDI Reactor (b) 


\section{RESULT AND DISCUSSION}

\section{Aviation Biofuel Production}

Aviation Biofuel production was carried out using two reactors. The total of HDO production (reactor 1) was $72.61 \%$. This result was ineffective because the HDO process in vegetable oils usually produce $80-86 \%$ paraffin hydrocarbons from $100 \%$ of feed [15]. During the reaction process in the reactor some hydrocarbon content was absorbed in the catalyst. The total product depends on the operational conditions and stability of the reactor. Aside from the total HDO products from reactor 1 process, there were by-products in the form of water and gas.

The formed HDO product was then fed into reactor 2 (HDI process). The results of HDI production of aviation biofuel production in reactor 2 amounted to $92.67 \%$, this showed that $92.67 \%$ of the total feed HDO products undergo an isomerization process in the reactor. Aside from the total HDI products from reactor 2 process, there was by-products in the form of gas.

\section{Pure Aviation Biofuel Analysis}

The analysis results of HDO and HDI product samples of TAN parameters, density at $15^{\circ} \mathrm{C}$, total sulfur content, freezing point, carbon distribution of $\mathrm{C}_{10}-\mathrm{C}_{14}$ and PION can be seen in Fig. 2 to 6 and Table 1. The standard refers to SNI: 8674 in 2018 concerning Pure Aviation Turbine Fuel.

\section{TAN}

TAN needed to be analysis to determine the acid content in samples expressed in $\mathrm{mg} \mathrm{KOH} / \mathrm{g}$. The smaller the TAN value, the more triglycerides were successfully converted to paraffin by the hydrogenation process. The TAN curve in the sample HDO and HDI products is interpreted in Fig. 2.

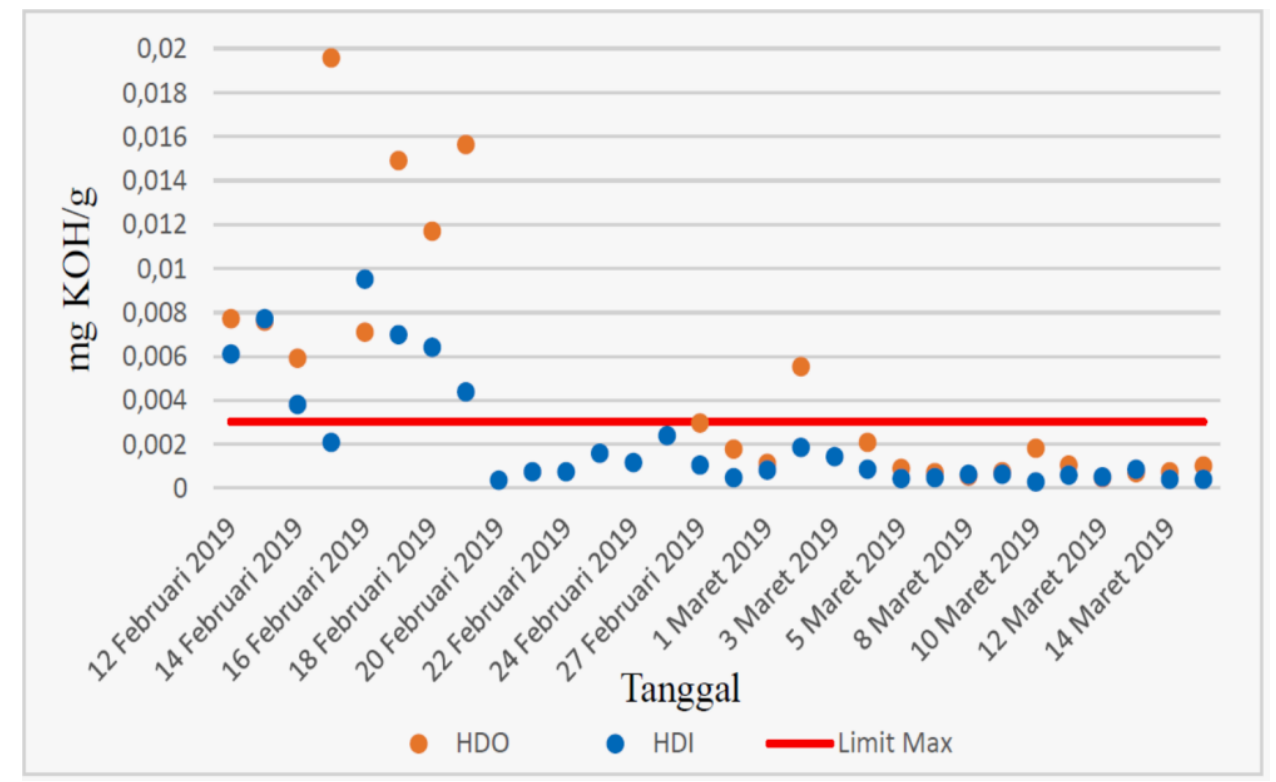

Fig. 2. TAN curve of HDO and HDI sample product

From Fig. 2, it appeared that the TAN value of HDI products was smaller and more stable compared to HDO products. This could be caused because the process in the isomerization reactor also affects the conversion of acid to paraffin by hydrogen.

\section{Density at $15{ }^{\circ} \mathrm{C}$}

Based on Fig. 3, the density values of HDO and HDI at $15{ }^{\circ} \mathrm{C}$ were below the maximum limit and above the minimum limit. Density of coconut oil (bait) has a density value of $893.7 \mathrm{~kg} / \mathrm{m}^{3}$. Aviation
Biofuel product samples are in accordance with SNI: 8674 in 2018 concerning pure Aviation Biofuel which is in the range of $748.0-840.0 \mathrm{~kg} / \mathrm{m}^{3}$. This value indicates that the Aviation Biofuel product has a lower intermolecular density than coconut oil due to the hydrotreating and isomerization processes. Density is a basic physical property that can characterize the light and heavy fractions of a fuel. The lower temperature density value of $15^{\circ} \mathrm{C}$ indicates the lighter the liquid's weight. 


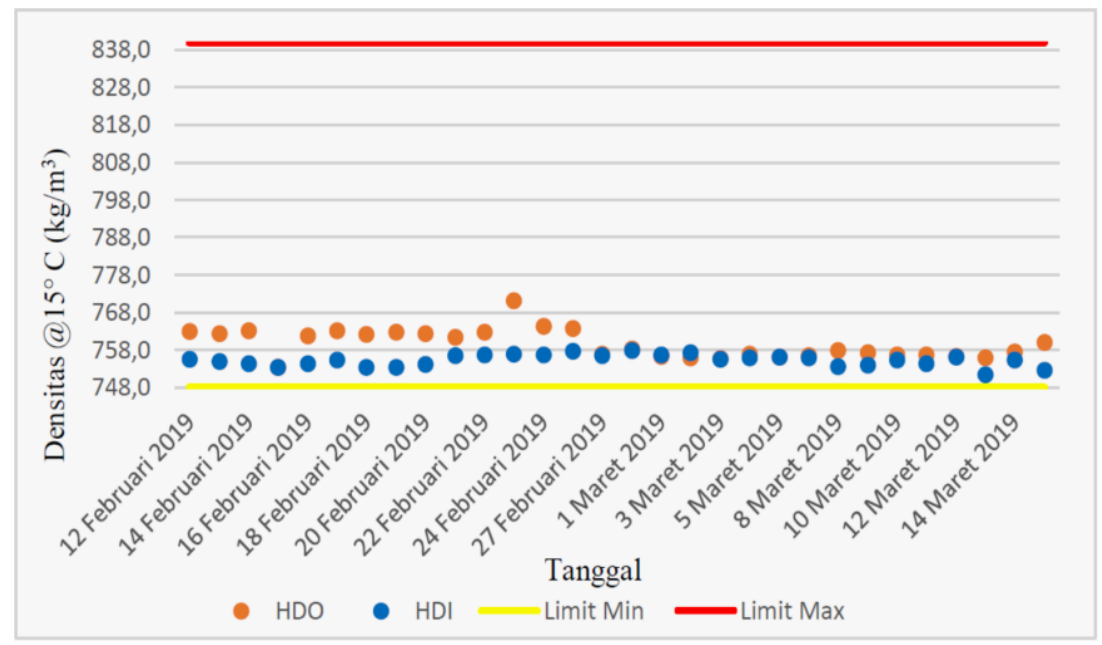

Fig. 3. Curve of density at $15{ }^{\circ} \mathrm{C}$ HDO and HDI product

\section{Total sulfur content}

From the results showed in Fig. 4, the total sulfur content in HDO and HDI product samples exceeded the established limit of $0.002 \%(\mathrm{w} / \mathrm{w})$. This could be caused by the catalyst activation process using sulfur before the process of Aviation Biofuel production took place. Most non-precious metal catalysts are activated by circulating hydrogen and sulfur-containing oils through the catalyst. Often, oil is given dimethyl sulfide $\left(\mathrm{CH}_{3}-\mathrm{S}-\mathrm{CH}_{3}\right)$ or dimethyl disulfide $\left(\mathrm{CH}_{3}-\mathrm{S}-\mathrm{S}-\mathrm{CH}_{3}\right)$ [16]. The temperature was slowly raised to the temperature of the decomposition of the sulfide. During dry sulfiding a mixture containing (2-5)\% volume of $\mathrm{H}_{2} \mathrm{~S}$ in hydrogen is flowed through the catalyst. The temperature was slowly raised to the temperature at which the unit was expected to operate. The process continues until the exit gas contains the same amount of $\mathrm{H}_{2} \mathrm{~S}$ as the inlet gas. The amount of $\mathrm{H}_{2} \mathrm{~S}$ that comes out indicates the catalyst was active. Therefore, the addition of sulfur when activating the catalyst must be considered in terms of both amount and concentration or a further process was needed to remove sulfur content in the sample such as by desulfurization. The average value for the total sulfur content of HDO products was $0.006 \%(\mathrm{w} / \mathrm{w})$ and for HDI products was $0.004 \%(\mathrm{w} / \mathrm{w})$.

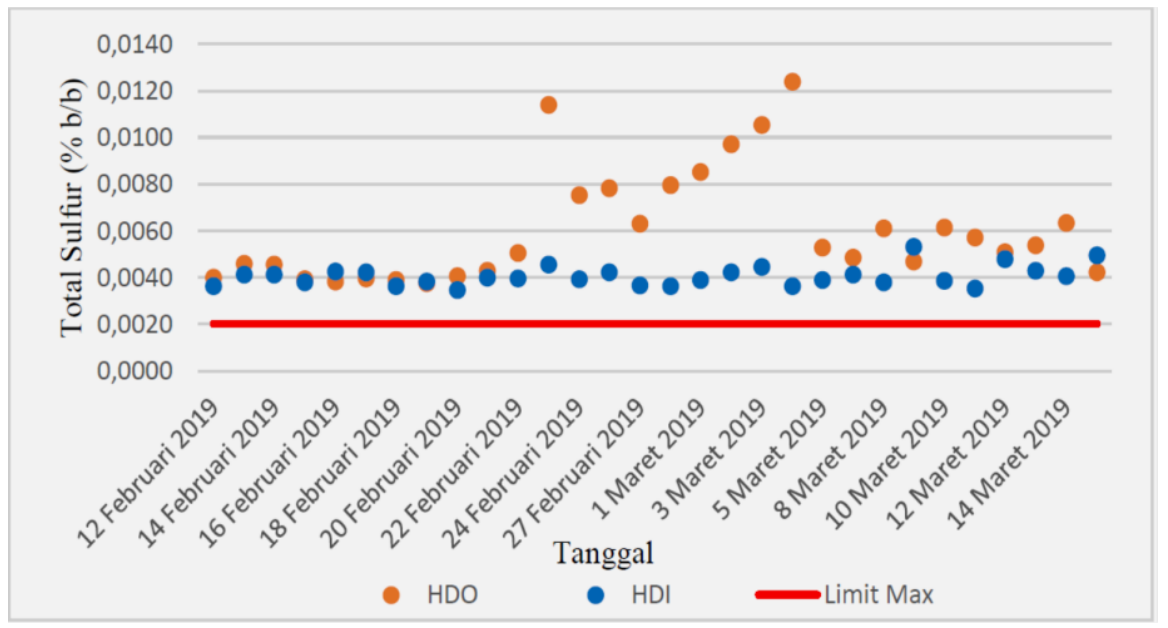

Fig. 4. Curve of total sulfur content of HDO and HDI products

\section{Freezing point}

Based on Fig. 5, the freezing point value of HDO product samples was still very far above the maximum limit set at the point of $-7.5^{\circ} \mathrm{C}$ and $-8.0^{\circ} \mathrm{C}$. Whereas
HDI products showed a freezing point value that was lower than HDO and experiences fluctuations every day. The flow rate was getting smaller or slower than the process in the reactor is longer, the 
feed contact with the catalyst was longer. So that the reaction took place more perfectly. In the following days the values were below the maximum limit.
Changes made did not have a significant effect on other test parameters so this treatment was considered appropriate to overcome this problem.

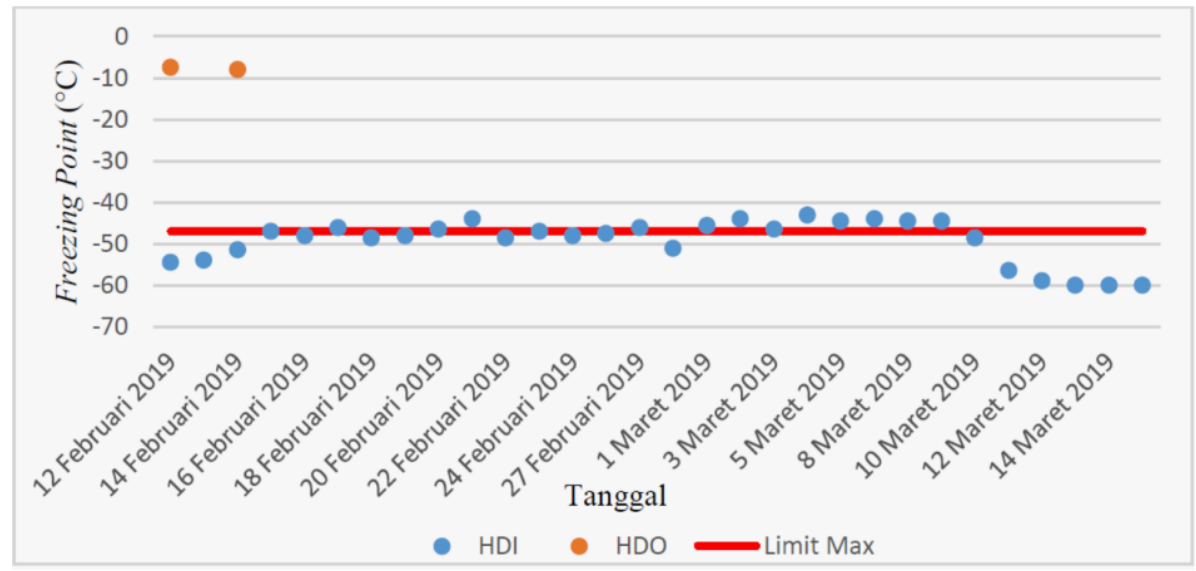

Fig. 5. Curve of Freezing point of HDO and HDI product

The difference in freezing point of HDO and HDI products could be influenced by the molecular structure of compounds. The freezing process of a liquid occurs when the temperature was lowered, so that the distance between the particles with each other gets closer and finally worked the attractive forces between molecules that were very strong. The existence of branching in the structure of alkanes (iso-paraffins), the molecular shape tends to resemble an irregular shape so that the surface area of the tangent plane or interactions that occur between molecules becomes reduced resulting in low inter-molecular tensile forces. Therefore, lower temperatures were needed for branched compounds to form crystals or freeze compared to branchless straight chain compounds.

Based on PION analysis in product samples, HDO products consisted mainly of n-paraffin which has no branches in the structural formula, so that temperatures were not too low to start freezing. Whereas HDI products were mostly paraffin isomers which have many branches in their structure, so it took a lower temperature than HDO products to start freezing.

\section{Carbon distribution of $\mathrm{C}_{10}-\mathrm{C}_{14}$}

Based on Fig. 6, the change of paraffin in the process of isomerization of HDO products to the largest HDI products occurs in $\mathrm{C}_{12}$ with a mole percent area of $32.49 \%$ to $6.67 \%$ mole and the $\mathrm{C}_{12}$ isomer increased from $0.60 \mathrm{~mol} \%$ to $29.23 \mathrm{~mol} \%$. The mole percent value of the sample area of HDO products in $\mathrm{C} 10-\mathrm{C} 14$ was high and low in the mole percent of the isomer area. Whereas the HDI products showed the opposite. This showed that there was a change in the shape of $\mathrm{C}_{10}-\mathrm{C}_{14}$ after the isomerization process.

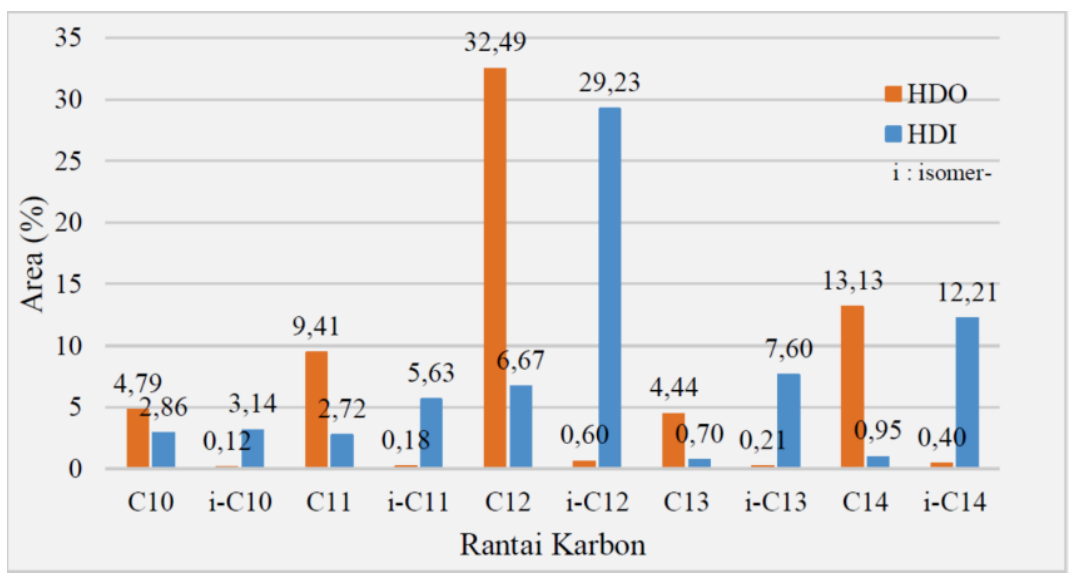

Fig. 6. Curve of $\mathrm{C}_{10}-\mathrm{C}_{14}$ carbon distribution of HDO and HDI products 


\section{PION}

Based on Table 1, the n-paraffin value in the HDO product sample decreased after the isomerization process with a value of $69.85 \%$ to $33.17 \%(\mathrm{v} / \mathrm{v})$ in the HDI product sample. While the value of iso-paraffin increased from $0.41 \%$ to $13.58 \%(\mathrm{v} / \mathrm{v})$ after the isomerization process. This showed that n-paraffin HDO products undergo a branching process into its isomeric form in an isomerization reactor producing HDI products. Likewise in naphthene compounds which were saturated hydrocarbons whose molecules have at least one ring structure or cycloparafin increased from $0.03 \%$ to $9.81 \%(\mathrm{v} / \mathrm{v})$ after the isomerization process and in olefins or alkenes compounds increased from $0.45 \%$ to $0.69 \%$ (v/v). According to ASTM D1655, iso-paraffin and naphthene, both contained in Aviation Turbine Fuels because of their stable nature, while olefin compounds, many unwanted substances were contained in fuels because they were easy to form gum despite having good combustion. Olefin in aircraft fuel was expected to $<1 \%$. Therefore, olefin would be saturated by the hydrotreating process. The n-paraffin compound in HDO products underwent an isomerization process into several isomeric forms such as branches, cyclic, and double [13].

Table 1. Results of PION analysis in HDO and HDI product samples

\begin{tabular}{|l|c|c|c|}
\hline \multirow{2}{*}{ PION Composition } & \multicolumn{3}{|c|}{ \% vol } \\
\cline { 2 - 4 } & HDO & HDI & Avtur \\
\hline Normal Paraffins & 69,85 & 33,17 & 29,86 \\
\hline Branched (Iso-Paraffins) & 0,41 & 13,58 & 24,32 \\
\hline Olefins & 0,45 & 0,69 & 6,77 \\
\hline Cycloparafins (Naftena) & 0,03 & 9,81 & 5,84 \\
\hline
\end{tabular}

The value of Aviation Biofuel after isomerization process (HDI) was close to the percentage value of Aviation Turbine Fuel. This indicated that Aviation Biofuel can be used as an alternative fuel to substitute Aviation Turbine Fuel from the PION parameter.

\section{Testing of aviation biofuel blending}

The results of Bio Aviation Turbine Fuel blending of $2 \%, 5 \%$, and $10 \%$ by volume were presented in Table 2 . The result showed that all aspects meet the standards set based on these test parameters. So that, the mixing of Aviation Biofuel as much as $(2,5$, and 10) \% in Aviation Turbine Fuel was acceptable and suitable for use.

Table 2. The Result of Aviation Biofuel Blending Testing

\begin{tabular}{|c|c|c|c|c|c|c|}
\hline \multirow{2}{*}{ No. } & \multirow{2}{*}{ Testing parameter } & \multirow{2}{*}{ Unit } & \multirow{2}{*}{ Standard* } & \multicolumn{3}{|c|}{ Aviation biofuel blending } \\
\cline { 5 - 7 } & & & $\mathbf{2 \%}$ & $\mathbf{5 \%}$ & $\mathbf{1 0 \%}$ \\
\hline 1. & $\mathrm{TAN}$ & $\mathrm{mg} \mathrm{KOH} / \mathrm{g}$ & Max 0,015 & 0,0010 & 0,0010 & 0,0011 \\
\hline 2. & Existent Gum & $\mathrm{mg} / 100 \mathrm{~mL}$ & $\operatorname{Max} 7,0$ & 2,7 & 3,8 & 4,3 \\
\hline 3. & Density at $15^{\circ} \mathrm{C}$ & $\mathrm{kg} / \mathrm{m}^{3}$ & $775,0-840,0$ & 803,7 & 802,0 & 799,7 \\
\hline 4. & Smoke Point & $\mathrm{mm}$ & Min 19,0 & 22,1 & 22,7 & 23,5 \\
\hline 5. & Freezing Point & ${ }^{\circ} \mathrm{C}$ & Max $-47,0$ & $-50,0$ & $-50,0$ & $-50,8$ \\
\hline 6. & Flash Point & ${ }^{\circ} \mathrm{C}$ & Min 38,0 & 44,5 & 44,8 & 44,8 \\
\hline 7. & Distillation & & & & & \\
\hline & Initial boiling point & ${ }^{\circ} \mathrm{C}$ & & 146,9 & 148,6 & 146,5 \\
\hline & $10 \%$ Recovery & ${ }^{\circ} \mathrm{C}$ & Max 205,0 & 169,6 & 170,4 & 170,2 \\
\hline & $50 \%$ Recovery & ${ }^{\circ} \mathrm{C}$ & & 198,5 & 198,6 & 199,5 \\
\hline & $90 \%$ Recovery & ${ }^{\circ} \mathrm{C}$ & & 236,1 & 235,6 & 237,1 \\
\hline & Final boiling point/End point & ${ }^{\circ} \mathrm{C}$ & Max 300,0 & 255,8 & 258,4 & 263,7 \\
\hline & Residue & $\% \mathrm{v} / \mathrm{v}$ & Max 1,5 & 1,2 & 1,2 & 1,2 \\
\hline 8. & Total sulfur content & $\% \mathrm{~b} / \mathrm{b}$ & Max 0,30 & 0,081 & 0,078 & 0,068 \\
\hline
\end{tabular}

* Defence standard 91-91 Turbine fuel, Kerosine type, AVTUR [8]

In the TAN analysis, the results were included in the stipulated conditions which are below $0.015 \mathrm{mg}$
$\mathrm{KOH} / \mathrm{g}$ with successive values for Bio Aviation Turbine Fuel 2\%, 5\% and 10\% i.e. $0.0010 \mathrm{mg}$ 
$\mathrm{KOH} / \mathrm{g}$; $0.0010 \mathrm{mg} \mathrm{KOH} / \mathrm{g}$; and $0.0011 \mathrm{mg} \mathrm{KOH} / \mathrm{g}$. This showed that the amount of Aviation Biofuel content in the mixture did not have a significant effect on the mixture. TAN was tested to find out the amount of acid in the fuel. In this case, acid was undesirable because it inclined to corrode metals that were in contact with or could damage the characteristics of water separation from aviation turbine fuel.

From the results of existent gum analysis, the value increased according to the increasing concentration of Aviation Biofuel that indicated the influence of Aviation Biofuel content in the mixture was quite significant. The existent gum analysis was conducted to determine the residual combustion produced due to the presence of heavy fraction contaminants in fuel samples [13]. High existent gum values indicated the possibility of oxidation in the fuel, so that oxidation results with high molecular weight did not dissolve in the fuel and go down as fine solids.

The result of density at $15^{\circ} \mathrm{C}$ parameter were in the specified standard range and showed that were inversely proportional. The higher concentration of Aviation Biofuel added, the lower the density value. This was due to Aviation Biofuel that has a lower density than Aviation Turbine Fuel, thus giving a significant influence on the mixture.

The smoke point analysis carried out to determine the content of aromatic compounds in the fuel. The lower the aromatic content, the higher the smoke point value. This relates to the aromatic nature which causes soot and smoke due to incomplete combustion. The results show that the higher the level of Aviation Biofuel blending, the higher the smoke point value. The addition of Aviation Biofuel can increasingly reduce the aromatic content in the fuel. This parameter complies with established standards of more than $19 \mathrm{~mm}$.

In the freezing point analysis, it showed that the $10 \%$ Aviation Biofuel mixture has a value of $-50.8^{\circ} \mathrm{C}$ and did not differ greatly with the mixed volume of $2 \%$ and $5 \%$. This could be interpreted that the isomeric form in the Aviation Biofuel was sufficient to influence the formation of crystals in fuels at low temperatures. In this case, the fuel can be survived not to crystallizing at temperatures up to $-50.8^{\circ} \mathrm{C}$. Freezing points in aircraft fuel were very important to know because temperatures at very low altitudes even reach less than $-20^{\circ} \mathrm{C}$. The minimum temperature experienced during a flight depends largely on the outside air temperature, flight duration, and aircraft speed. For example, long duration flights will require lower freezing point fuels than short duration flights [13]. Therefore, in order for an aircraft to still be able to operate above altitude, aircraft fuel was required to have a low freezing point value.

From the flash point analysis results, the Aviation Biofuel content in the mixture showed a value that indicated the flammable or volatile compounds in the Aviation Biofuel were stable and included in the conditions of aircraft fuel acceptance which was more than $38.0^{\circ} \mathrm{C}$. Flash point analysis was carried out to determine the character of the fuel liquid. This point showed the content of volatile compounds in a sample expressed in temperature. As the temperature increased, the vapor pressure increased, so that the concentration of vapors from flammable liquids in the air also increased and produced a flash.

The distillation analysis results showed the fuel evaporates at temperatures below the maximum standard of $205.0^{\circ} \mathrm{C}$. Moreover, at the final boiling point (FBP) or the final boiling point the fuel evaporates when heating was below the standard maximum limit of $300{ }^{\circ} \mathrm{C}$ for all percent of Aviation Biofuel. If the FBP value is more than specified, the fuel still contains a heavy fraction that is difficult to evaporate [13].

The residual value in all Aviation Biofuel percentages is $1.2 \%$ below the maximum standard of $1.5 \%$ by volume, indicating the fuel did not produce a lot of residue that can cause damage or blockage to the engine. When the airplane was airborne, the air temperature get lower which affects the combustion process of the fuel, so it was important to know the plane's fuel boiling point. In aircraft fuel, boiling points affect the onset, heating, and tendency of the fuel to turn into steam at high operating temperatures or at high altitudes.

The analysis of total sulfur content obtained consecutive results of $0.081 \%(\mathrm{w} / \mathrm{w}), 0.078 \%(\mathrm{w} / \mathrm{w})$, and $0.068 \%(\mathrm{w} / \mathrm{w})$ for $2 \%, 5 \%$ and $10 \%$ Aviation Biofuel by volume. It was the higher the percent mixture, the lower the total value of the sulfur content. This was because the Aviation Biofuel added has a total sulfur content of $0.004 \%(\mathrm{w} / \mathrm{w})$ and the total value of the sulfur content of Aviation Turbine Fuel used was $0.08 \%(\mathrm{w} / \mathrm{w})$. So the more Aviation Biofuel content in the mixture gave the effect of reducing the total sulfur content in the mixture. In aircraft fuel products, the total sulfur content was important to know because if it reacted with oxygen in the form of gas, it would form SOx which has a negative impact on the environment. In addition, the presence of sulfur in fuels was undesirable because if oxidized it can cause corrosion to the engine [13]. 


\section{CONCLUSION AND RECOMMENDATIONS}

\section{Conclusion}

Based on the experimental results, it can be concluded that the Aviation Biofuel was made using hydroprocessing with the total sulfur content in the Aviation Biofuel not in accordance with SNI: 8674 in 2018 concerning pure Aviation Biofuel, but it complied for TAN, density at $15{ }^{\circ} \mathrm{C}$, and freezing point parameters. Aviation Biofuel blending of $2 \%$, $5 \%$, and $10 \%$ were in accordance with the Aviation Biofuel Defence Standard 91-91 Turbine Fuel, Kerosine Type, AVTUR specifications for all parameters.

\section{Recommendations}

Based on experiments, it is suggested that pure Aviation Biofuel needs further analysis for other parameters. In addition, further processing is needed for the total removal of sulfur content in the production of pure Aviation Biofuel.

\section{ACKNOWLEDMENTS}

The authors wish to thank to PT Pertamina Research and Technology Center (RTC) for providing the research fund.

\section{REFERENCES}

1. Ardhia, W., 2014. Perkiraan Kebutuhan Depo Pengisian Avtur Pesawat Udara di Indonesia: Jurnal Perhubungan Udara. Vol 40:163-172. Jakarta. Indonesia.

2. Laksmono, Rudy., A. Datumaya., \& Z. Abidin. 2016. Analysis Bioavtur for Energy Security. Jurnal Pertahanan. Vol 3. Universitas Pertahanan Indonesia. Indonesia.

3. Chevron. 2006. Aviation Fuels Technical Review. Chevron Corporation. Houston. Texas. Amerika.

4. Jacobson, K., K. C. Maheria. \& K. Ajay. 2013. Renewable and Sustainable Energy Reviews. Journal Bio-oil Valorization: A Review 23:91-106.

5. Iata. 2019. Carbon Offsetting for International Aviation. International Air Transport Association. Geneva. Switzerland.

\section{Cheppy Asnadi, Difany Tsabita Islami \\ Department of Chemical Analysis, Politeknik AKA Bogor \\ 16154, Bogor, Indonesia}

\section{Septhian Marno, Nelliza Putri, Wawan Rustyawan}

Pertamina Research and Technology Centre

Jl. Raya Bekasi KM 20, Pulogadung,

Jakarta Timur, Indonesia
6. Prastowo, Bambang. \& N. Richana. 2014. Biofuel Generasi 1 dan Generasi 2. Badan Penelitian dan Pengembangan Pertanian. Jakarta.

7. Peraturan menteri energi dan sumber daya mineral republik indonesia No. 12. 2015. Perubahan Ketiga Atas Peraturan Menteri Energi Dan Sumber Daya Mineral Nomor 32 Tahun 2008 Tentang Peyediaan, Pemanfaatan, Dan Tata Niaga Bahan Bakar Nabati (Biofuel) Sebagai Bahan Bakar Lain. Kementerian ESDM. Indonesia

8. Defence Standard 91-91. 2011. Turbine Fuel, Kerosine Type, Jet A-1, NATO Code: F-35, Joint Service Designation: AVTUR. Ministry of Defence. United Kingdom. England.

9. Veriansyah, Bambang \& Young Han, Jae \& Kim, Seok-Ki \& Hong, Seung-ah \& Jun Kim, Young \& Lim, Jong Sung \& Shu, Young-Wong \& Oh, Seong-Geun \& Kim, Jaehoon. 2011. Production of renewable diesel by hydroprocessing of soybean oil: Effect of catalysts. Elsevier. USA.

10. ASTM D3242. 2017. Acidy in Aviation Turbine Fuel. Copyright Annual Book of ASTM Standard. United States.

11. ASTM D381. 2017. Gum Content in Fuels by Jet Evaporation. Copyright Annual Book of ASTM Standard. Unites States.

12. Standar Nasional Indonesia (SNI): 8674. 2018. Bioavtur Murni /Biojet. Jakarta. Indonesia.

13. ASTM D1655. 2009. Standar Spesification for Aviation Turbine Fuel. Copyright Annual Book of ASTM Standard. United States.

14. ASTM D86. 2017. Distillation of Petroleum Products and Liquid Fuels at Atmospheric Pressure1. Copyright Annual Book of ASTM Standard. United States.

15. Starck, L., L. Pidol., N. Jeuland., T. Chapus., P. Bogers., \& J. Bauldreay. 2016. Production of Hydroprocessed Esters and Fatty Acids (HEFA) Optimisation of Process Yield. Journal Oil \& Gas Science and Technology. Vol 71. United Kingdom.

16. Robinson, P.R. \& G.E. Dolbear. 2015. Hydrotreating and Hydrocracking: Fundamentals. Katy Institute for Sustainable Energy. United States.

\author{
Poppy Sri Lestari \\ Department of Industrial Waste Treatment \\ Politeknik AKA Bogor, \\ Bogor 16154, Indonesia \\ Phone: +62-813-948-942-07 \\ e-mail: poppy.srilestari@gmail.com
}

